\section{Non-cystic fibrosis bronchiectasis}

\section{Maeve P Murray MB ChB MRCP, Clinical} Research Fellow

Adam T Hill MB ChB MD FRCPE, Consultant Respiratory Physician and Honorary Senior Lecturer

Department of Respiratory Medicine, Royal Infirmary of Edinburgh, Scotland

Clin Med 2009;9:164-9

Originally described by Laennac in $1819,{ }^{1}$ bronchiectasis is a chronic, debilitating condition characterised by persistent cough, excessive sputum production and recurrent chest infections. The precise prevalence is unknown, but figures quoted vary from about $4 \times 10^{5}$ aged $18-34$ years to $272 \times 10^{5}$ aged 75 years and over. ${ }^{2,3}$
Pathologically, there is abnormal permanent dilatation of the airways. This leads to impaired mucociliary clearance, which in turn leads to a vicious cycle of bacterial colonisation in normally sterile airways and excessive bronchial inflammation. This review explores current clinical practice for this complex condition.

\section{Diagnosis}

There is usually a history of a chronic productive cough and recurrent chest infections. There may be symptoms related to airways obstruction (wheeze and breathlessness), mucus plugging (chest pain) and also systemic symptoms. ${ }^{4}$ The diagnosis of bronchiectasis is confirmed radiologically with computed

\section{Key Points}

Bronchiectasis should be considered in patients with a chronic, productive cough and a history of recurrent chest infections

The gold standard for diagnosis is computed tomography of the chest

The aetiology is unknown in up to $50 \%$ of cases and post-infective in up to $42 \%$

The mainstays of treatment are regular chest physiotherapy, annual influenza vaccination and prompt administration of antibiotics for exacerbations

Long-term antibiotics should be considered for patients with recurrent chest infections impacting on their health-related quality of life

KEY WORDS: bronchiectasis, exacerbations, investigations, management tomography of the chest. The defining characteristic is bronchial dilatation with the internal diameter of the bronchial lumen greater than that of the adjacent artery, categorised as tubular, varicose or cystic (Figs 1(a), 1(b) and 1(c)).

\section{Aetiology}

No underlying cause is identified in up to $50 \%$ of cases and is post-infective in up to $42 \% .{ }^{6,7}$ The common causes, appropriate investigations and expected abnormal findings are listed in Table $1 .^{6,7}$

\section{Assessment of severity}

Clinical, radiological and microbiological features guide clinicians to the severity of bronchiectasis. These investigations not only provide clinicians with a quantitative assessment of disease severity but may also help in the management of both stable disease and exacerbations.

- Sputum colour and volume. Colour is graded as mucoid, mucopurulent or purulent (Fig 2) and volume is measured over a 24-hour collection period. Patients with severe bronchiectasis usually have purulent sputum and volumes that may exceed $25 \mathrm{ml} /$ day, even when stable.

- Exacerbation frequency. In severe disease there are often multiple exacerbations (usually $\geq 3$ a year) and inpatient management may be necessary.
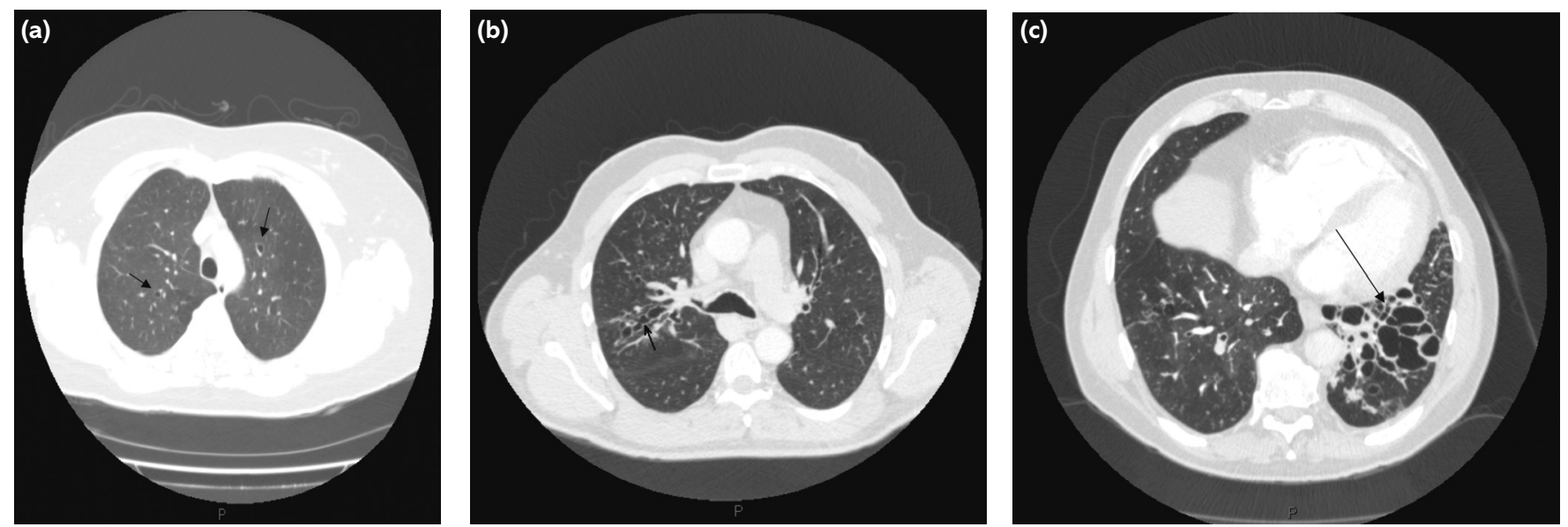

Fig 1. (a) Tubular dilation of airways (see arrow); (b) varicose dilatation of airways (arrow shows irregular, dilated airway); (c) cystic dilatation of airways with thickened bronchi and mucus plugging (see arrow). 
- Lung function. There can be advanced airflow obstruction in severe bronchiectasis, but there may also be restrictive or normal patterns.

- Radiological findings. In severe disease bronchial dilatation is usually varicose or cystic with multiple lobes affected. There may be associated bronchial wall thickening, mucus plugging and subsegmental, segmental or lobar collapse.

- Sputum microbiology. Most patients with severe bronchiectasis are chronically colonised with pathogenic organisms in their sputum when stable. ${ }^{8}$ Typical organisms include Haemophilus influenzae, Streptococcus pneumoniae, Staphylococcus aureus,

Table 1. Investigating the aetiology of non-cystic fibrosis (CF) bronchiectasis.

\begin{tabular}{|c|c|c|c|}
\hline Aetiology & $\begin{array}{l}\text { Incidence } \\
\qquad(\%)\end{array}$ & Investigations & Expected abnormal findings \\
\hline $\begin{array}{l}\text { Post-infectious } \\
\text { (eg pneumonia, pertussis, } \\
\text { Mycobacterium tuberculosis) }\end{array}$ & $29-42$ & $\begin{array}{l}\text { - History of previous infection } \\
\text { - Radiological evidence of previous } \\
\text { infection }\end{array}$ & $\begin{array}{l}\text { Radiological evidence of previous infection } \\
\text { (eg old, healed TB etc) }\end{array}$ \\
\hline $\begin{array}{l}\text { CTD (commonly RA, also } \\
\text { systemic sclerosis, SLE, } \\
\text { relapsing polyarthritis, } \\
\text { ankylosing spondylitis) }\end{array}$ & $3-6$ & $\begin{array}{l}\text { - History of CTD } \pm \text { vasculitis } \\
\text { - Autoimmune screen, including } \\
\text { RF, ANAs, ANCAs }\end{array}$ & $\begin{array}{l}\text { Positive autoantibody screen may occur with or } \\
\text { without clinical evidence of CTD }\end{array}$ \\
\hline ABPA & $1-7$ & $\begin{array}{l}\text { - Full blood count } \\
\text { - Total lgE } \\
\text { - Specific lgE and lgG to Aspergillus } \\
\text { fumigatus } \\
\text { - } \text { A. fumigatus skin-prick test } \\
\text { - Spirometry (FEV }, \text { FVC) } \\
\text { - HRCT }\end{array}$ & $\begin{array}{l}\text { Criteria to diagnose ABPA in patients with } \\
\text { bronchiectasis include: } \\
\text { - history of asthma } \\
\text { - peripheral blood eosinophlia } \\
\text { - } \quad \text { total IgE } \\
\text { - central bronchiectasis on HRCT } \\
\text { - } \quad \text { +ve skin test reactivity to } A \text {. fumigatus } \\
\text { - } \uparrow \text { specific serum IgE and IgG to } A \text {. fumigatus }\end{array}$ \\
\hline $\begin{array}{l}\text { Immunodeficiency } \\
\text { (typically CVI, X-linked } \\
\text { agammaglobulinaemia, } \\
\text { IgA deficiency) }\end{array}$ & $1-8$ & $\begin{array}{l}\text { - } \lg G, \lg A, \lg M \\
\text { - } \text { IgG subclasses } \\
\text { Baseline specific antibody levels } \\
\text { against tetanus toxoid and } \\
\text { polysaccharide capsules of } \\
\text { Streptococcus pneumoniae and } \\
\text { Haemophilus influenzae type } B\end{array}$ & $\begin{array}{l}\text { - Deficiencies as per condition } \\
\text { - Low levels of IgG subclass } 2 \text { associated with } \\
\text { recurrent infections with Gram +ve } \\
\text { encapsulated organisms } \\
\text { - Low baseline antibody response; should be } \\
\text { immunised with the appropriate vaccine and } \\
\text { antibody response rechecked at } 21 \text { days }\end{array}$ \\
\hline CF & $3-4$ & $\begin{array}{l}\text { - Cytogenetics for CFTR receptor } \\
\text { mutations } \\
\text { - Sweat test }\end{array}$ & $\begin{array}{l}\text { - Positive CFTR mutations } \\
\text { - Positive sweat test } \\
\text { - Should be reserved for patients } \leq 40 \text { years, } \\
\text { clinical features of malabsorption, history of } \\
\text { male infertility, upper lobe bronchiectasis on } \\
\text { HRCT, recurrent Staphylococcus aureus in } \\
\text { sputum or other organisms typically identified } \\
\text { in CF }\end{array}$ \\
\hline $\begin{array}{l}\text { Ciliary defect } \\
\text { (eg primary ciliary dyskinesia) }\end{array}$ & $2-4$ & $\begin{array}{l}\text { History of chronic upper respiratory } \\
\text { tract problems, otitis media, male } \\
\text { infertility } \\
\text { Referral for specialist investigations: } \\
\text { direct examination of cilia, saccharin } \\
\text { test etc }\end{array}$ & $\begin{array}{l}\text { - Abnormal ciliary beat pattern } \pm \text { frequency } \\
\text { - Saccharin taste test (saccharin not tasted after } \\
60 \mathrm{~min} \text { ) }\end{array}$ \\
\hline IBD & 1 & $\begin{array}{l}\text { - History } \\
\text { - Gl opinion and specialist } \\
\text { investigations }\end{array}$ & NA \\
\hline $\begin{array}{l}\text { Aspiration/inhalation of } \\
\text { foreign body }\end{array}$ & 4 & $\begin{array}{l}\text { - Bronchoscopy if history of } \\
\text { aspiration or localised (single lobe) } \\
\text { bronchiectasis }\end{array}$ & - Foreign body in airway(s) \\
\hline Idiopathic & $30-35$ & - Above causes excluded & - Diagnosis of exclusion \\
\hline
\end{tabular}

$\mathrm{ABPA}=$ allergic bronchopulmonary aspergillosis; $\mathrm{ANA}=$ antinuclear antibody; $\mathrm{ANCA}=$ antineutrophil cytoplasmic antibody; $\mathrm{CF}=$ cystic fibrosis; CFTR = CF transmembrane regulator; CTD = connective tissue disease; $C V I=$ common variable immunodeficiency; GI = gastrointestinal; HRCT = high-resolution computed tomography; IBD = inflammatory bowel disease; Ig =immunoglobulin; NA = not applicable; RA = rheumatoid arthritis; RF = rheumatoid factor; SLE = systemic lupus erythematosus; TB = tuberculosis. 
Moraxella catarrhalis and, in patients with advanced bronchiectasis, Pseudomonas aeruginosa. Patients colonised with $P$. aeruginosa have a poor health-related quality of life (HRQL), more severe airways obstruction and perhaps an accelerated decline in $\mathrm{FEV}_{1} \cdot{ }^{9,10}$

\section{Management of stable disease}

Management aims to reduce symptoms, limit exacerbations, preserve lung function and improve HRQL.

\section{Patient education}

Patients should be advised on smoking cessation, chest clearance techniques and

Fig 2. Sputum chart.

Sputum is graded as mucoid, mucopurulent or purulent. long-term treatments. They should receive annual influenza vaccinations, the pneumococcal vaccination and prompt antibiotic treatment for infections.

\section{Physiotherapy}

The normal mucociliary clearance mechanism is impaired in bronchiectasis. Although randomised controlled trials (RCTs) assessing the efficacy of sputum clearance are lacking, physiotherapy is advised to promote clearance. Traditional postural drainage exercises can be difficult; newer techniques such as the active cycle breathing technique and assisted devices (eg the flutter) have been developed for patient ease. These have similar outcomes to postural drainage but are associated with greater patient preference. ${ }^{11,12}$ All patients should be reviewed by a specialist chest physiotherapist.

Adjuncts to physiotherapy. Several adjuncts have been proposed, including bronchodilator therapy, inhaled hyperosmolar agents (nebulised hypertonic saline, inhaled mannitol) and inhaled mucolytics (recombinant human DNase). Bronchodilator therapy (see below) may be used prior to chest physiotherapy to minimise bronchial hyperreactivity and improve airway clearance. Nebulised hypertonic $7 \%$ saline has been shown to yield greater sputum weights with greater ease and less viscosity, and small studies have shown that inhaled mannitol improves mucociliary clearance. ${ }^{13,14}$ Further studies are needed, but currently the latter two agents are not used in routine clinical practice.

Recombinant human DNase aims to reduce sputum viscosity, but a Cochrane review ${ }^{15}$ did not find enough evidence to support its regular use in bronchiectasis, and a multicentre study found it had a significant negative impact on $\mathrm{FEV}_{1} \cdot{ }^{16}$

\section{Bronchodilators}

The role of bronchodilator therapy is yet to be established, but may be used as an adjunct to physiotherapy and to relieve breathlessness. If there is evidence of airways obstruction, reversibility testing should be performed to determine whether the patient could benefit from inhaled $\beta_{2}$-agonists and/or anticholinergics. Both, however, may provide symptomatic relief of breathlessness, with or without an objective improvement in $\mathrm{FEV}_{1}$. A trial of the short-acting agents is recommended in the first instance in patients with impaired lung function and consideration of long-acting agents if clinical improvement. ${ }^{17,18}$

\section{Inhaled corticosteroids}

To date, RCTs of inhaled corticosteroids have shown a reduction in 24-hour sputum volume and improvement in HRQL, but no impact on $\mathrm{FEV}_{1}$ or exacerbation frequency. ${ }^{19-21}$ These studies used high-dose inhaled corticosteroids (fluticasone $500 \mu \mathrm{g}$ bd or beclometasone 
$750 \mu \mathrm{g}$ bd) but the optimal dose needs further clarification. A six-month trial of inhaled corticosteroids may be warranted, particularly for patients with evidence of airway obstruction and reversibility or with severe bronchiectasis.

\section{Long-term antibiotics}

The rationale for prescribing long-term antibiotics (oral or nebulised) is to reduce the bacterial burden in the airways, limiting inflammation and promoting healing of the bronchial tree.

Oral antibiotics. RCTs of long-term oral antibiotics for bronchiectasis are limited. In a 12-month Medical Research Council randomised placebo-controlled trial of tetracycline there was reduction in sputum volume, purulence and the number of days absent from work due to ill health. ${ }^{22}$ An eight-month randomised placebo-controlled trial of high-dose daily oral amoxicillin (3 g BD) found clinical improvement, reduction in 24-hour sputum volume, purulence and days absent from work, with the treatment well tolerated. ${ }^{23}$ Open label studies ( $\geq 6$ months) assessing the role of macrolides have shown a reduction in exacerbation frequency. ${ }^{24,25}$ Oral treatment is inexpensive but systemic side effects are common.

Nebulised antibiotics. These offer a targeted therapy with limited systemic side effects. However, they are expensive and may be less well tolerated due to bronchospasm, even with adjunctive treatment with a $\beta_{2}$-agonist. To date, the RCTs of long-term nebulised antibiotics have included only patients chronically colonised with $P$. aeruginosa. Two studies compared twice daily nebulised tobramycin with placebo, one cyclically ( 4 weeks treatment, 2 weeks off) and the other daily for six months. ${ }^{26,27}$ In both studies there was a reduction in bacterial density in the sputum but a small increased incidence of bronchospasm in the treatment arms. Another study compared nebulised ceftazidime and tobramycin with placebo for 12 months. Although there was no reduction in overall exacerbation frequency in the active group, the number and duration of hospital admissions for exacerbations were reduced. ${ }^{28}$

Further studies are needed to define who would benefit from long-term antibiotics and to determine the optimum treatment. Currently, long-

Table 2. Recommended antibiotic therapy for exacerbations of bronchiectasis based on previous sputum microbiology.

\begin{tabular}{|c|c|c|}
\hline Organism & First-line treatment* & Second-line treatment ${ }^{*}$ \\
\hline $\begin{array}{l}\text { Streptococcus pneumoniae or } \\
\text { Haemophilus influenzae } \\
\text { ( } \beta \text {-lactamase-negative) }\end{array}$ & $\begin{array}{l}\text { Amoxicillin } 500 \mathrm{mg} \text { TDS } \\
\text { or Amoxicillin } 1 \mathrm{~g} \text { TDS or } \\
3 \mathrm{~g} \mathrm{BD} \text { in severe disease }\end{array}$ & Clarithromycin 500 mg BD \\
\hline $\begin{array}{l}\text { Haemophilus influenzae } \\
\text { ( } \beta \text {-lactamase-positive) or } \\
\text { Moraxella catarrhalis }\end{array}$ & Co-amoxiclav $625 \mathrm{mg}$ TDS & $\begin{array}{l}\text { Doxycycline } 100 \mathrm{mg} \text { BD or } \\
\text { Clarithromycin } 500 \mathrm{mg} \text { BD or } \\
\text { Ciprofloxacin } 500 \mathrm{mg} \mathrm{BD} \text { or } \\
\text { Ceftriaxone } 1-2 \mathrm{~g} \mathrm{OD} \mathrm{(iv)}\end{array}$ \\
\hline Staphylococcus aureus & Flucloxacillin 500 mg QDS & Clarithromycin 500 mg BD \\
\hline $\begin{array}{l}\text { MRSA } \\
\text { oral therapy }\end{array}$ & $\begin{array}{l}<50 \mathrm{~kg} \text { : Rifampicin } 450 \mathrm{mg} \text { OD + } \\
\text { trimethoprim } 200 \mathrm{mg} \mathrm{BD} \\
\geq 50 \mathrm{~kg} \text { : Rifampicin } 600 \mathrm{mg} \text { OD + } \\
\text { trimethoprim } 200 \mathrm{mg} \mathrm{BD}\end{array}$ & $\begin{array}{l}<50 \mathrm{~kg} \text { : Rifampicin } 450 \mathrm{mg} \text { OD+ } \\
\text { doxycycline } 200 \mathrm{mg} \text { OD } \\
\geq 50 \mathrm{~kg}: \text { Rifampicin } 600 \mathrm{mg} \text { OD + } \\
\text { doxycycline } 200 \mathrm{mg} \text { OD }\end{array}$ \\
\hline MRSA & Vancomycin (iv**) or Teicoplanin (iv**) & Linezolid** (oral or iv) \\
\hline $\begin{array}{l}\text { Coliforms } \\
\text { (eg Klebsiella, Enterobacter) }\end{array}$ & Ciprofloxacin 500 mg BD & Ceftriaxone $1-2 \mathrm{~g}$ OD (iv) \\
\hline Pseudomonas aeruginosa & $\begin{array}{l}\text { Ciprofloxacin } 500 \text { mg BD (or, in severe } \\
\text { infections Ciprofloxacin } 750 \text { mg BD) }\end{array}$ & $\begin{array}{l}\text { Monotherapy: } \\
\text { ceftazidime } 2 \mathrm{~g} \text { (iv) TDS or } \\
\text { tazocin } 4.5 \mathrm{~g} \text { (iv) TDS or } \\
\text { aztreonam } 2 \mathrm{~g} \text { (iv) TDS or } \\
\text { meropenem } 1 \mathrm{~g} \text { (iv) TDS } \\
\text { Dual therapy*: } \\
\text { Each of the above may be combined with } \\
\text { either: gentamicin (iv) or tobramycin (iv) or } \\
\text { colomycin (iv) }\end{array}$ \\
\hline $\begin{array}{l}\text { If no previous sputum samples or if } \\
\text { previous sputum microbiology shows } \\
\text { mixed normal flora or no pathogens }\end{array}$ & Amoxicillin $500 \mathrm{mg}$ TDS & Clarithromycin 500 mg BD \\
\hline
\end{tabular}


term antibiotics may be indicated in those who have frequent exacerbations (usually $\geq 3 /$ year) that impact on their HRQL.

\section{Surgery}

Indications for surgery include major haemoptysis or localised disease causing significant morbidity not responsive to medical management. Reported outcomes from surgery are good but studies were not randomised and in practice referral for surgical intervention is rare. ${ }^{29}$

\section{Management of exacerbations}

Prompt antibiotic treatment is recommended for patients presenting with increasing cough, sputum volume and purulence. There are many unanswered questions, including mode, choice and duration of antibiotic, monotherapy or dual agents and how best to assess response to treatment.

\section{Antimicrobial agents}

Sputum should be sent for microbiological culture at the start of all exacerbations and empirical treatment commenced immediately based on previous sputum microbiology, if available (see Table 2). Treatment should only be adjusted if there is no clinical response and should then be guided by the sputum culture and sensitivity results.

\section{Oral versus intravenous treatment}

Oral antibiotic therapy should be used as first-line management unless:

- the culture of pathogenic organisms sensitive only to intravenous agents

- patients have clinical sepsis necessitating acute inpatient admission

- there has been a failure of response to oral antimicrobials.

\section{Monotherapy or dual antibiotic therapy?}

Monotherapy is recommended for exacerbations due to $S$. pneumoniae,
H. influenzae, M. catarrhalis, or methicillin-sensitive $S$. aureus (MSSA). To prevent further resistance emerging, two antibiotics are recommended for patients colonised with methicilinresistant $S$. aureus (MRSA) and in patients with $P$. aeruginosa with multiple frequent exacerbations.

\section{Duration}

The optimum duration of treatment is unknown. In one study, inflammatory response returned to normal within a week of antimicrobial therapy, but symptomatic improvement has generally been seen in studies employing 10-14 days of treatment. ${ }^{30}$ At present, antibiotics are recommended for 10-14 days.

\section{Other adjuncts to treatment}

Regular chest physiotherapy is recommended. Patients with increased wheeze and dyspnoea may require optimisation of their bronchodilator therapy, including steroids.

\section{Assessing response}

It is helpful for clinicians to have endpoints to assess response to treatment. Bacterial clearance, 24-hour sputum volume, C-reactive protein and the St George's Respiratory Questionnaire (an HRQL questionnaire) are useful markers of treatment response, although the latter questionnaire is predominantly a research tool. ${ }^{31,32}$

\section{Conclusions}

There has been a resurgence of interest in the previously neglected condition of bronchiectasis. Ongoing and future RCTs will provide stronger evidence-based treatment for this chronic disabling disease.

\section{References}

1 Laennec RT. A treatise in the diseases of the chest and on mediate auscultation, 4th edn, 1819. Translation: Forbes J. London: Longman, 1834.

2 Weycker D, Edelsberg J, Oster G, Tino G. Prevalence and economic burden of bronchiectasis. Clin Pulm Med 2005;12: 205-9.

3 Twiss J, Metcalfe R, Edwards E, Byrnes C. New Zealand national incidence of bronchiectasis 'too high' for a developed country. Arch Dis Child 2005;90:737-40.

4 King PT, Holdsworth SR, Freezer NJ, Villanueva E, Holmes PW. Characterisation of the onset and presenting clinical features of adult bronchiectasis. Respir Med 2006; 100:2183-9.

5 Naidich DP, McCauley DI, Khouri NF, Stitik FP, Siegelman SS. Computed tomography of bronchiectasis. J Comput Assist Tomogr 1982;6:437-44.

6 Nicotra MB, Rivera M, Dale AM et al. Clinical, pathophysiologic, and microbiologic characterization of bronchiectasis in an aging cohort. Chest 1995;108:955-61.

7 Pasteur MC, Helliwell SM, Houghton SJ et al. An investigation into causative factors in patients with bronchiectasis. Am J Respir Crit Care Med 2000;162(4 Pt 1):1277-84.

8 Angrill J, Agusti C, de Celis R et al. Bacterial colonisation in patients with bronchiectasis: microbiological pattern and risk factors. Thorax 2002;57:15-9.

9 Davies G, Wells AU, Doffman S, Watanabe S, Wilson R. The effect of Pseudomonas aeruginosa on pulmonary function in patients with bronchiectasis. Eur Respir J 2006;28:974-9.

10 Martinez-Garcia MA, Soler-Cataluna JJ, Perpina-Tordera M, Roman-Sanchez P, Soriano J. Factors associated with lung function decline in adult patients with stable non-cystic fibrosis bronchiectasis. Chest 2007;132:1565-72.

11 Patterson JE, Bradley JM, Hewitt O, Bradbury I, Elborn JS. Airway clearance in bronchiectasis: a randomized crossover trial of active cycle of breathing techniques versus Acapella. Respiration 2005;72: 239-42.

12 Thompson CS, Harrison S, Ashley J, Day K, Smith DL. Randomised crossover study of the Flutter device and the active cycle of breathing technique in non-cystic fibrosis bronchiectasis. Thorax 2002;57:446-8.

13 Kellett F, Redfern J, Niven RM. Evaluation of nebulised hypertonic saline (7\%) as an adjunct to physiotherapy in patients with stable bronchiectasis. Respir Med 2005; 99:27-31.

14 Daviskas E, Anderson SD, Eberl S, Young IH. Effect of increasing doses of mannitol on mucus clearance in patients with bronchiectasis. Eur Respir J 2008;31: 765-72.

15 Crockett AJ, Cranston JM, Latimer KM, Alpers JH. Mucolytics for bronchiectasis. Review. Cochrane Database Syst Rev 2001; (1):CD001289.

16 O’Donnell AE, Barker AF, Ilowite JS, Fick RB. Treatment of idiopathic bronchiectasis with aerosolized recombinant human 
DNase I. rhDNase Study Group. Chest 1998;113:1329-34.

17 Franco F, Sheikh A, Greenstone M. Short acting beta-2 agonists for bronchiectasis. Review. Cochrane Database Syst Rev 2003; (3):CD003572.

18 Sheikh A, Nolan D, Greenstone M. Longacting beta-2-agonists for bronchiectasis. Cochrane Database Syst Rev 2001;(4): CD002155.

19 Elborn JS, Johnston B, Allen F et al. Inhaled steroids in patients with bronchiectasis. Respir Med 1992;86:121-4.

20 Martinez-Garcia MA, Perpina-Tordera M, Roman-Sanchez P, Soler-Cataluna JJ. Inhaled steroids improve quality of life in patients with steady-state bronchiectasis. Respir Med 2006;100:1623-32.

21 Tsang KW, Tan KC, Ho PL et al. Inhaled fluticasone in bronchiectasis: a 12 month study. Thorax 2005:60:239-43

22 Prolonged antibiotic treatment of severe bronchiectasis; a report by a subcommittee of the Antibiotics Clinical Trials (nontuberculous) Committee of the Medical Research Council. BMJ 1957;2:255-9.

23 Currie DC, Garbett ND, Chan KL et al. Double-blind randomized study of prolonged higher-dose oral amoxycillin in purulent bronchiectasis. Q J Med 1990; 76:799-816.

24 Cymbala AA, Edmonds LC, Bauer MA et al. The disease-modifying effects of twice-weekly oral azithromycin in patients with bronchiectasis. Treat Respir Med 2005;4:117-22.

25 Davies G, Wilson R. Prophylactic antibiotic treatment of bronchiectasis with azithromycin. Thorax 2004;59:540-1.

26 Barker AF, Couch L, Fiel SB et al. Tobramycin solution for inhalation reduces sputum Pseudomonas aeruginosa density in bronchiectasis. Am J Respir Crit Care Med 2000;162(2 Pt 1):481-5.

27 Drobnic ME, Sune P, Montoro JB, Ferrer A, Orriols R. Inhaled tobramycin in noncystic fibrosis patients with bronchiectasis and chronic bronchial infection with Pseudomonas aeruginosa. Ann Pharmacother 2005;39:39-44.

28 Orriols R, Roig J, Ferrer J et al. Inhaled antibiotic therapy in non-cystic fibrosis patients with bronchiectasis and chronic bronchial infection by Pseudomonas aeruginosa. Respir Med 1999;93:476-80.

29 Balkanli K, Genc O, Dakak M et al.
Surgical management of bronchiectasis: analysis and short-term results in 238 patients. Eur J Cardiothorac Surg 2003; 24:699-702.

30 Tsang KW, Chan WM, Ho PL et al. A comparative study on the efficacy of levofloxacin and ceftazidime in acute exacerbation of bronchiectasis. Eur Respir J 1999;14:1206-9.

31 Murray MP, Turnbull K, Macquarrie S, Hill AT. Assessing response to treatment of exacerbations of bronchiectasis in adults. Eur Respir J 2009 Feb;33(2):312-8.

32 Wilson CB, Jones PW, O'Leary CJ, Cole PJ, Wilson R. Validation of the St. George's Respiratory Questionnaire in bronchiectasis. Am J Respir Crit Care Med 1997;156(2 Pt 1):536-41. 